\title{
Erwinia mallotivora sp. nov., the Causal Organism of Bacterial Leaf Spot of Mallotus japonicus Muell. Arg.
}

\author{
MASAO GOTO \\ Faculty of Agriculture, Shizuoka University, Shizuoka, 422 Japan
}

\begin{abstract}
Bacterial leaf spot of Mallotus japonicus, first reported by Takimoto in 1930, was recently found in Japan, and the causal agent was studied taxonomically. The pathogen was assigned to the "Erwinia amylovora group." The bacterium attacked M. japonicus, producing small, dark-brown spots on leaves as well as shoot blight. Japanese pear, peach, apple, plum, Japanese apricot, and chestnut trees could not be infected. The new isolates differed from $E$. amylovora in gelatin liquefaction and in ability to produce acid from xylose, mannose, cellobiose, glycerol, mannitol and to utilize formate. The new isolates are regarded as belonging to a new species, for which the name Erwinia mallotivora is proposed. Strain AM1 (= NCPPB 2851) is designated as the type strain. E. mallotivora differs from Aplanobacter mollatii (sic) Takimoto, 1930, the validity of which is considered doubtful.
\end{abstract}

A bacterial leaf spot of Mallotus japonicus (Japanese common name: Akamegashiwa) was first reported by Takimoto in 1930 and was attributed to a new species, Aplanobacter mollatii (sic) (12). Thereafter, no additional information on either the etiology or epiphytology of the disease has been available, and further occurrence of the disease has not been reported. Cultures of $A$. mollatii (sic) have not been available from any type-culture collection and the scientific name has not been cited in any edition of Bergey's Manual. The name is listed in Index Bergeyana (1), where it is indicated to be illegitimate. In 1975, however, a bacterial disease characterized by the formation of numerous brown spots was found on the leaves of $M$. japonicus growing in Hamamatsu City, Shizouka Prefecture; the symptoms of this disease were identical to those described by Takimoto.

This paper deals with the results of a taxonomic study of the pathogenic bacterium of bacterial leaf spot of $M$. japonicus.

\section{MATERIALS AND METHODS}

The 10 strains (AM1 through AM10) used in this study were isolated from lesions formed on the leaves of $M$. japonicus collected at Hamamatsu City, Shizuoka Prefecture, in June 1975 by the author.

The methods of Dye (3) were used to test for the following characters: oxygen requirement, production of a reducing substance from sucrose, $\mathrm{NaCl}$ tolerance, growth factor requirements, asparagine utilization, amino acid decarboxylase, oxidase, catalase, lipase, starch hydrolysis, esculin hydrolysis, levan formation, temperature relationships, and ability to produce potato rot. The methods described by Cowan and Steel (2) were followed in testing for the following characters: oxidative-fermentative test, methyl red test, acetoin production (Barritt method), KCN tolerance, malonate utilization and phenylalanine deaminase (method of Shaw and Clarke), gelatin hydrolysis, reaction in litmus milk, indole production (method 3 ), urease production (method 1), production of nitrite from nitrate, $\mathrm{H}_{2} \mathrm{~S}$ production (method 3 ), gluconate oxidation (method 1 ), and phosphatase production. Nitrate reduction was also tested in a synthetic medium (11). Pectate liquefaction was tested with Paton's pectate gel medium (13). Egg yolk medium was prepared by the method of Lelliott et al. (6). Production of acid from carbohydrates was tested in $1 \%$ peptone water containing bromocresol purple $(0.7 \mathrm{ml}$ of $1.5 \%$ alcoholic solution) as a pH indicator plus $1 \%$ (wt/vol) carbon sources (3). The method of Klement et al. (4) was used for testing tobacco hypersensitivity. Poly- $\beta$ hydroxybutyrate accumulation was detected by staining with Sudan Black B.

Erwinia amylovora antiserum with a titer of 1/ 1,000 was provided by the courtesy of $R$. A. Lelliott, Plant Pathology Laboratory, Ministry of Agriculture, Fisheries and Food, in Harpenden, England. This antiserum was used without dilution in slide agglutination tests.

The determination of the guanine plus cytosine $(\mathrm{G}+\mathrm{C})$ content of the deoxyribonucleic acid (DNA) was made by T. Kimura, Department of Fisheries, Hokkaido University, Hakodate, Japan, using the method of Marmur and Doty $(7,10)$.

For pathogenicity tests, seedlings of $M$. japonicus were grown in a greenhouse. The unfolded leaves were inoculated by both spray and pin-prick methods with bacteria suspended in water at a concentration of approximately $10^{8}$ cells $/ \mathrm{ml}$; the suspensions were prepared from 24-h-old potato-sucrose agar slant cultures. Also, wound inoculations were made by scratching the surfaces of leaves with a needle previously dipped into the bacterial suspension. Inoculated plants or leaves were maintained 
overnight under humid conditions either by covering with polyethylene bags or by placing them in a humid chamber. Inoculations were also made on mature shoots of peach (Prunus persica var. vulgaris, cv: wasesuimitsu), apple (Malus pumila var. domestica, cv: unknown), Japanese pear (Pyrus sinensis var. culta, cv: chojuro), Japanese apricot (Prunus mume, cv: shirokaga), chestnut (Castanea crenata, cv: tanbaguri), and plum (Prunus triflora, cv: sordan) trees, each about 10 years old.

\section{RESULTS}

Symptoms. Under natural conditions, the disease was seen on the new leaves which developed in early May through June. Watersoaked and dark green spots measuring 0.5 to $1.0 \mathrm{~mm}$ in diameter were scattered on the leaf lamina. A large number of lesions often formed alongside the thick veins. The individual lesions slowly enlarged and became restricted by small veins, turning into polygonal shaped, dark-brown spots, 2 to $3 \mathrm{~mm}$ in diameter (Fig. 1). With heavy infection, the spots coalesced, killing an entire leaf, and often shoot blight was induced. Yellow haloes approximately 1 $\mathrm{mm}$ wide were usually formed around the darkbrown lesions. Under humid conditions, the undersurface of the lesions showed an oily, shiny appearance due to the bacterial exudates.

Inoculations. After inoculation with pure cultures of the bacterium by the puncturing method, water-soaked lesions appeared after 5 days around the sites of inoculation and developed into leaf spots typical of those found in natural infection. With spray inoculation, the first symptoms appeared 7 to 10 days after inoculation as minute, water-soaked lesions and developed the same as those due to natural infections. When young shoots were inoculated by spraying, heavy infections often occurred on leaves near the apex and resulted in shoot blight. The small lesions were produced on stems, but they did not enlarge to cause dieback of the infected shoot.

On matured shoots of peach, apple, Japanese pear, chestnut, Japanese apricot, and plum trees, brown necrotic spots with a dried appearance and measuring 0.5 to $1.0 \mathrm{~mm}$ in diameter were formed on twigs and leaves after a week, but no further enlargement was observed. On the leaves of peach, Japanese apricot, and plum inoculated by puncturing, the brown necrotic spots soon dropped out as an abscission layer developed around the lesions. No infection occurred by spray inoculation on either the leaves or twigs of these plants.

Soft rot was not induced on potato slices inoculated with the bacterium. A positive tobacco hypersensitivity reaction was obtained by infiltration to leaves of the bacterial suspensions at a concentration of about $10^{9}$ cells per ml.

Description of the new isolates. The cells of the strains studied were gram-negative, nonen-
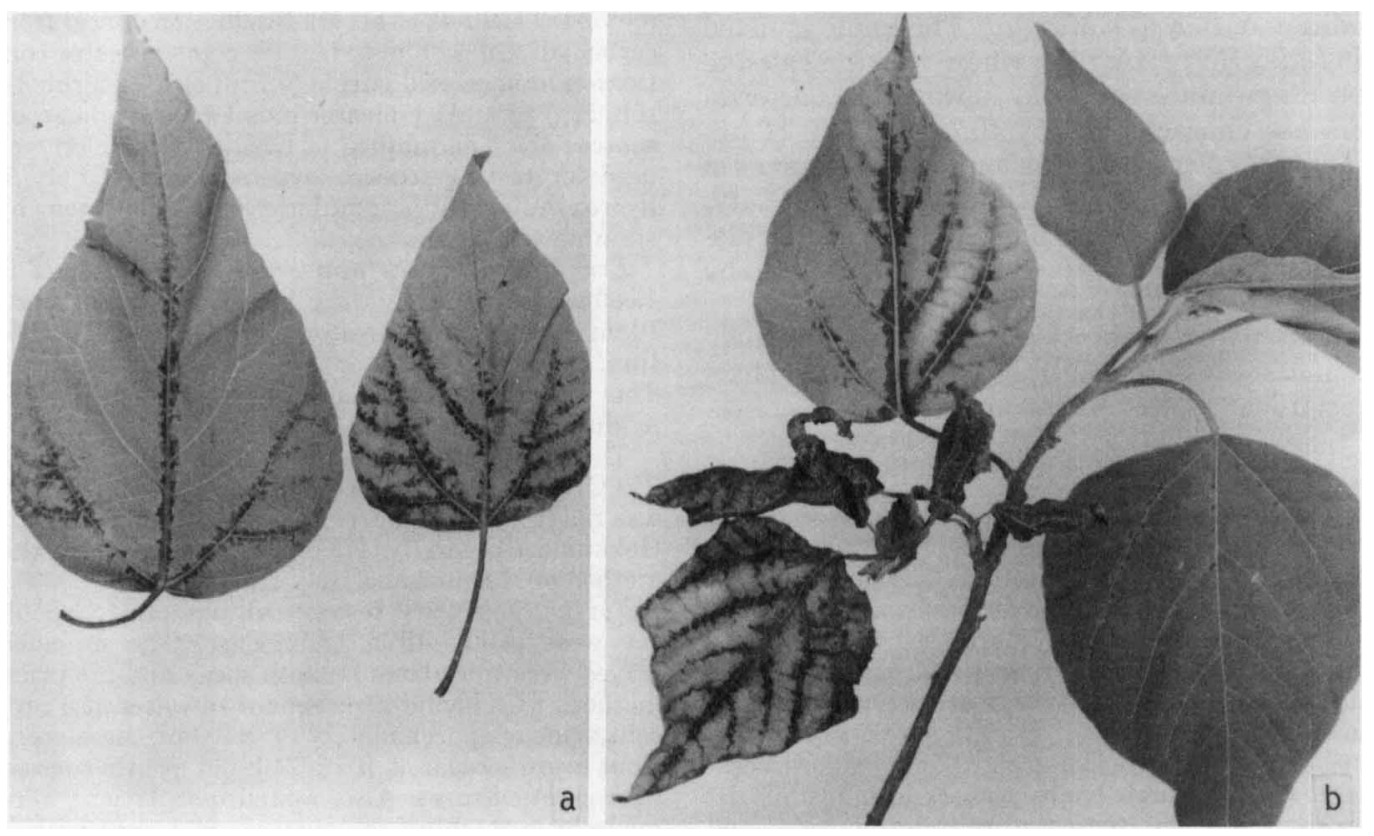

FIG. 1. Symptoms of bacterial leaf spot of $M$. japonicus. (a) Lesions formed on leaves alongside the thick veins; (b) blighted young shoot. $(\times 0.35)$ 


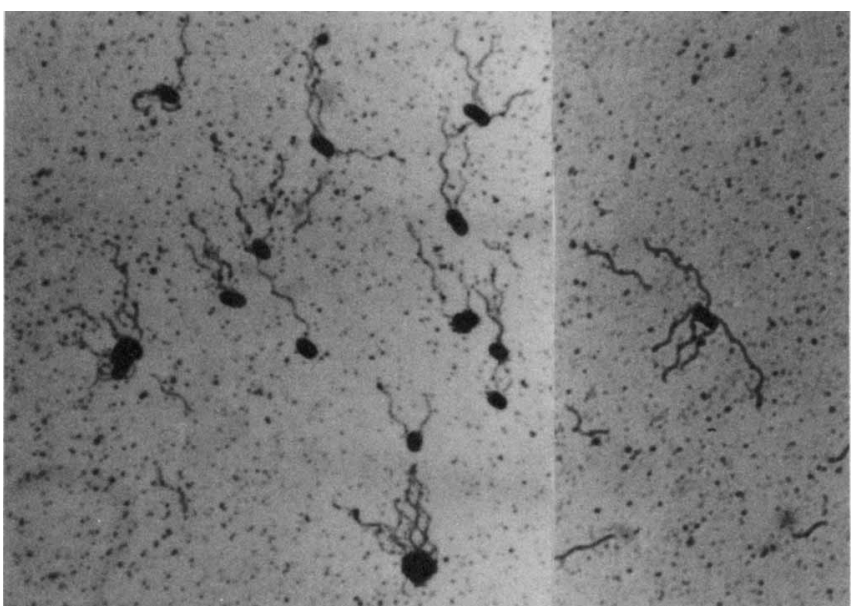

FIg. 2. Peritrichous cells of strain AM1. Magnification, $\times 2,000$.

capsulated, nonsporeforming rods. Poly- $\beta$-hydroxybutyrate was not formed. The cells were peritrichous and were motile by means of three to six flagella (Fig. 2).

On nutrient agar plates without the addition of sucrose, colonies were white, raised, transparent, and circular with smooth surfaces and entire margins; they measured about $1 \mathrm{~mm}$ in diameter after 2 days and 2.0 to $2.5 \mathrm{~mm}$ after 5 days. Colonies formed on $5 \%$ sucrose nutrient agar plates $24 \mathrm{~h}$ after inoculation were 1.5 to 2.0 $\mathrm{mm}$ in diameter, flat, white, circular with entire margins and smooth surfaces, butyrous, and transparent. After 4 days of incubation, these colonies measured 3 to $5 \mathrm{~mm}$ in diameter and were domed, circular, white, mucoid, and translucent and sometimes possessed radial striations. Abundant levan formation was characteristic on this medium. No water-soluble or non-water-soluble pigments were produced.

The organism did not grow in the synthetic medium with glucose as a sole source of carbon. Growth in the synthetic medium was supported by the addition of yeast extract at a concentration of $1 \mathrm{mg} / \mathrm{ml}$ but not by supplement with nicotinic acid at $1 \mu \mathrm{g} / \mathrm{ml}$. Asparagine was not utilized as the sole source of carbon and nitrogen.

Other characteristics of these strains are given in Table 1.

Serological relationship to Erwinia amylovora. An agglutination reaction was not observed in slide tests with cells of the new isolates and $E$. amylovora antiserum.

DNA base composition. The $\mathrm{G}+\mathrm{C}$ contents of strains AM1 and AM5 were 51.02 and 49.81 mol\% (buoyant density and $T_{m}$ ), respectively, which were in the lower range of $\mathrm{G}+\mathrm{C}$ values for members of the genus Erwinia.

\section{DISCUSSION}

The symptoms of the disease of $M$. japonicus reported here are similar to those of the bacterial leaf spot described by Takimoto in 1930 . In addition, a photograph of the symptoms of the disease which appeared in a book by Okabe (8) also clearly indicates that the two diseases are identical, for Takimoto provided Okabe with a photograph for publication in the above-mentioned book (Okabe, personal communication). However, there are a number of differences between the bacteriological characteristics of A. mollatii (sic) Takimoto and those of the presently described bacterium. Takimoto's original description of $A$. mollatii (sic) is as follows: "Non-motile, nonencapsulated, gramnegative rods which form circular, orange-yellow colonies on nutrient agar plates. Aerobic. Positive reactions in both gelatin liquefaction and $\mathrm{H}_{2} \mathrm{~S}$ production. Starch hydrolysis was strongly positive. Nitrate reduction and indole production were negative. Litmus milk turned blue and peptonized without coagulation. Acid was not produced from glucose, sucrose, lactose or glycerol in the basal medium containing peptone. Maximum growth temperature and thermal death point were 35 and $47^{\circ} \mathrm{C}$, respectively" (translated from the Japanese). These characters suggest that $A$. mollatii (sic) should be assigned to the genus Xanthomonas (9).

On the other hand, the characters of the new isolates indicate that the isolates belong to the genus Erwinia and have a close relationship to $E$. amylovora. Although they differ from $E$. amylovora in host-range patterns, the new isolates differ from $E$. amylovora only in gelatin liquefaction and in the abilities to produce acid from several organic compounds, such as man- 
TABLE 1. Characteristics of 10 strains of the causal organism of bacterial leaf spot of Mallotus japonicus

\begin{tabular}{|c|c|c|c|c|c|c|c|c|c|c|}
\hline \multirow{2}{*}{ Properties } & \multicolumn{10}{|c|}{ Characteristics $^{a}$ of strain: } \\
\hline & AM1 & AM2 & AM3 & AM4 & AM5 & AM6 & AM7 & AM8 & AM9 & AM10 \\
\hline Anaerobic growth & + & + & + & + & + & + & + & + & + & + \\
\hline Growth factor required & + & + & + & + & + & + & + & + & + & + \\
\hline Nicotinic acid required & - & - & - & - & - & - & - & - & - & - \\
\hline $\mathrm{H}_{2} \mathrm{~S}$ production & - & - & - & - & - & - & - & - & - & - \\
\hline Urease & - & - & - & - & - & - & - & - & - & - \\
\hline Growth at $36^{\circ} \mathrm{C}$ & - & - & - & - & - & - & - & - & - & - \\
\hline Gluconate oxidation & - & - & - & - & - & - & - & - & - & - \\
\hline Reducing substances from sucrose & + & + & + & + & + & + & + & + & + & + \\
\hline Pectate degradation & - & - & - & - & - & - & - & - & - & - \\
\hline Pink diffusible pigment & - & - & - & - & - & - & - & - & - & - \\
\hline Acetoin production & + & + & + & + & + & + & + & + & + & + \\
\hline Mucoid growth & + & + & + & + & + & + & + & + & + & + \\
\hline Motility & + & + & + & + & + & + & + & + & + & + \\
\hline Nitrate reduction & - & - & - & - & - & - & - & - & - & - \\
\hline Gelatin liquefaction & - & - & - & - & - & - & - & - & - & - \\
\hline Phenylalanine deaminase & - & - & - & - & - & - & - & - & - & - \\
\hline Indole production & - & - & - & - & - & - & - & - & - & - \\
\hline Gas from glucose & - & - & - & - & - & - & - & - & - & - \\
\hline Casein hydrolysis & - & - & - & - & - & - & - & - & - & - \\
\hline Blue pigment & - & - & - & - & - & - & - & - & - & - \\
\hline Yellow pigment & - & - & - & - & - & - & - & - & - & - \\
\hline Cottonseed oil hydrolysis & - & - & - & - & - & - & - & - & - & - \\
\hline KCN inhibition & + & + & + & + & + & + & + & + & + & + \\
\hline Maximum growth temp. $\left(32^{\circ}-33^{\circ} \mathrm{C}\right)$ & + & + & + & + & + & + & + & + & + & + \\
\hline Growth in $5 \% \mathrm{NaCl}$ & - & - & - & - & - & - & - & - & - & - \\
\hline Growth in $4 \% \mathrm{NaCl}$ & + & + & + & + & + & + & + & + & + & + \\
\hline OF test & $\mathbf{F}$ & $\mathbf{F}$ & $\mathbf{F}$ & $\mathbf{F}$ & $F$ & $\mathbf{F}$ & $\mathbf{F}$ & $\mathrm{F}$ & $\mathbf{F}$ & $\mathbf{F}$ \\
\hline Phosphatase & - & - & - & - & - & - & - & - & - & - \\
\hline Litmus milk reaction & $\mathrm{D}$ & D & $\mathrm{D}$ & $\mathrm{D}$ & $\mathrm{D}$ & D & $\mathrm{D}$ & D & $\mathrm{D}$ & $\mathrm{D}$ \\
\hline Potato rot & - & - & - & - & - & - & - & - & - & - \\
\hline Tobacco hypersensitivity & + & + & + & + & + & + & + & + & + & + \\
\hline Kovacs oxidase & - & - & - & - & - & - & - & - & - & - \\
\hline Catalase reaction & + & + & + & + & + & + & + & + & + & + \\
\hline MR test & + & + & + & + & + & + & + & + & + & + \\
\hline Starch hydrolysis & - & - & - & - & - & - & - & - & - & - \\
\hline Malonate & - & - & - & - & - & - & - & - & - & - \\
\hline Arginine and lysine decarboxylase & - & - & - & - & - & - & - & - & - & - \\
\hline Egg-yolk reaction & - & - & - & - & - & - & - & - & - & - \\
\hline Poly- $\beta$-hydroxybutyrate & - & - & - & - & - & - & - & - & - & - \\
\hline $\begin{array}{l}\text { Agglutination with } E \text {. amylovora antise- } \\
\text { rum }\end{array}$ & - & - & - & - & - & - & - & - & - & - \\
\hline \multicolumn{11}{|l|}{ Carbohydrate fermentation: } \\
\hline Arabinose & - & - & - & - & - & - & - & - & - & - \\
\hline Mannitol & + & + & + & + & + & + & + & + & + & + \\
\hline Salicin & - & - & - & - & - & - & - & - & - & - \\
\hline$\alpha$-Methyl-glucoside & - & - & - & - & - & - & - & - & - & - \\
\hline Xylose & + & + & + & + & + & + & + & + & + & + \\
\hline Raffinose & - & - & - & - & - & - & - & - & - & - \\
\hline Dulcitol & - & - & - & - & - & - & - & - & - & - \\
\hline Inositol & - & - & - & - & - & - & - & - & - & - \\
\hline Lactose & - & - & - & - & - & - & - & - & - & - \\
\hline Melezitose & - & - & - & - & - & - & - & - & - & - \\
\hline Melibiose & - & - & - & - & - & - & - & - & - & - \\
\hline Maltose & - & - & - & - & - & - & - & - & - & - \\
\hline Adonitol & - & - & - & - & - & - & - & - & - & - \\
\hline Cellobiose & $+d$ & $+d$ & $+d$ & $+d$ & $+d$ & $+d$ & $+d$ & $+d$ & $+d$ & $+d$ \\
\hline Dextrin & - & - & - & - & - & - & - & - & - & - \\
\hline Esculin & - & - & - & - & - & - & - & - & - & - \\
\hline Glycerol & $+d$ & $+d$ & $+\mathrm{d}$ & $+d$ & $+d$ & $+\mathrm{d}$ & $+d$ & $+\mathrm{d}$ & $+d$ & $+\mathrm{d}$ \\
\hline Mannose & + & + & + & + & + & + & + & + & + & + \\
\hline
\end{tabular}


TABLE 1-Continued

\begin{tabular}{|c|c|c|c|c|c|c|c|c|c|c|}
\hline \multirow{2}{*}{ Properties } & \multicolumn{10}{|c|}{ Characteristics $^{a}$ of strain: } \\
\hline & AM1 & AM2 & AM3 & AM4 & AM5 & AM6 & AM7 & AM8 & AM9 & AM10 \\
\hline \multicolumn{11}{|c|}{ Carbohydrate fermentation: Continued } \\
\hline Rhamnose & - & - & - & - & - & - & - & - & - & - \\
\hline Ribose & + & + & + & + & + & + & + & + & + & + \\
\hline Sorbitol & - & - & - & - & - & - & - & - & - & - \\
\hline Inulin & - & - & - & - & - & - & - & - & - & - \\
\hline Starch & - & - & - & - & - & - & - & - & - & - \\
\hline Galactose & + & + & + & + & + & + & + & + & + & + \\
\hline Sucrose & + & + & + & + & + & + & + & + & + & + \\
\hline Trehalose & + & + & + & + & + & + & + & + & + & + \\
\hline Glucose & + & + & + & + & + & + & + & + & + & + \\
\hline Fructose & + & + & + & + & + & + & + & + & + & + \\
\hline Malate & + & + & + & + & + & + & + & + & + & + \\
\hline Succinate & + & + & + & + & + & + & + & + & + & + \\
\hline Citrate & + & + & + & + & + & + & + & + & + & + \\
\hline Formate & - & - & - & - & - & - & - & - & - & - \\
\hline Lactate & - & - & - & - & - & - & - & - & - & - \\
\hline Galacturonate & - & - & - & - & - & - & - & - & - & - \\
\hline Tartrate & - & - & - & - & - & - & - & - & - & - \\
\hline
\end{tabular}

${ }^{a}$ Symbols: B, blue; D, decolorization; d, delayed fermentation in 10 to 14 days of incubation; F, fermentation; $\mathrm{P}$, peptonization.

TABLE 2. Acid production from carbohydrates by $E$. mallotivora, A. mollatii (sic) and the species of the $E$. amylovora group

\begin{tabular}{|c|c|c|c|c|c|c|c|c|}
\hline Substrate & 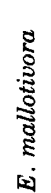 & 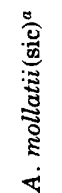 & 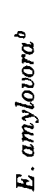 & 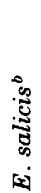 & 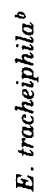 & 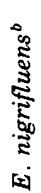 & 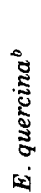 & 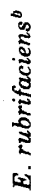 \\
\hline Arabinose & $-c$ & NT & $\mathrm{d}$ & - & - & + & - & + \\
\hline Mannitol & + & NT & - & + & - & + & + & + \\
\hline Salicin & - & NT & - & + & - & + & + & - \\
\hline$\alpha$-Methyl glucoside & - & NT & - & - & - & - & + & + \\
\hline Xylose & + & NT & - & - & - & + & - & - \\
\hline Raffinose & - & NT & - & + & - & + & - & - \\
\hline Dulcitol & - & NT & - & - & - & - & - & - \\
\hline Inositol & - & $\mathrm{NT}$ & - & + & - & + & - & - \\
\hline Lactose & - & - & - & - & - & - & - & - \\
\hline Melezitose & - & NT & - & - & - & - & - & - \\
\hline Melibiose & - & NT & - & + & - & + & - & - \\
\hline Maltose & - & $\mathrm{NT}$ & - & - & - & - & - & - \\
\hline Adonitol & - & $\mathrm{NT}$ & - & - & - & - & - & - \\
\hline Cellobiose & + & $\mathrm{N}^{\prime} \mathrm{T}$ & - & - & - & - & - & - \\
\hline Dextrin & - & NT & - & - & - & - & - & - \\
\hline Esculin & - & $\mathrm{NT}$ & - & + & - & + & + & - \\
\hline Glycerol & + & - & - & $\mathrm{d}$ & - & + & + & d \\
\hline Mannose & + & NT & - & + & - & + & + & + \\
\hline Rhamnose & - & $\mathrm{NT}$ & - & - & - & + & - & - \\
\hline Ribose & + & NT & + & + & - & + & + & + \\
\hline Sorbitol & - & NT & $\mathrm{d}$ & + & - & + & + & + \\
\hline
\end{tabular}

a Takimoto, 1930

${ }^{\circ}$ See reference 5 .

$c$ Symbols: d, $80 \%$ or more of strains positive; NT, not tested.

nitol, xylose, cellobiose, glycerol, and mannose, and to utilize formate. These results substantiate the conclusion that the new isolates be included in the "E. amylovora group."
Dye (3) made an extensive study of the bacteria of the $E$. amylovora group and proposed that each species of the group be regarded as a subspecies (variety) of E. amylovora, e.g., E. amy- 
lovora subsp. salicis. However, Lelliott (5), in the 8th edition of Bergey's Manual, placed the organisms of the $E$. amylovora group in six separate species, and it is Lelliott's treatment that is followed here.

In Tables 2 and 3 , the characteristics of the new isolates are compared with those of $A$. mollatii (sic) and the species in the E. amylovora group. The new isolates differ from the other organisms in the ability to produce acids from carbohydrates as well as in some other characters and in pathogenicity. Therefore, the new isolates, which cause bacterial leaf spot of $M$. japonicus, are regarded as belonging to a new species, for which the name Erwinia mallotivora is proposed (mal.lo.ti'vo.ra. M.L.n. Mallotus a genus of trees; L. v. vora to devour; M.L.adj. mallotivora Mallotus-destroying). Strain AM1 is designated as the type strain of $E$. mallotivord. Three strains of the new species, including the type strain, were deposited in the National Collection of Plant Pathogenic Bacteria (NCPPB), Harpenden, Herts, England, under the accession numbers 2851 (= AM1), 2852 (= AM2), and 2853 (= AM5). It is possible that two different bacteria, A. mollatii (sic) and $E$. mallotivora, cause diseases on $M$. japonicus with the same symptoms. Although two or more different bacteria may be pathogenic to the same plant, the diseases they cause usually are different with respect to their syndromes or symptoms and are distinguishable one from the other. However, the symptoms of the disease caused by E. mallotivora, whether naturally or artificially produced, are so close to those described by Takimoto as being produced by $A$. mollatii (sic) that it is difficult to consider that the causative agents belong to different genera. Not only is A. mollatii (sic) poorly described by today's standards but also the scientific name is illegitimate (1). Takimoto's original cultures of $A$. mollatii (sic) are

TABLE 3. Biochemical, physiological, and cultural characters of E. mallotivora, A. mollatii (sic), and the species of the E. amylovora group

\begin{tabular}{|c|c|c|c|c|c|c|c|c|}
\hline Character & 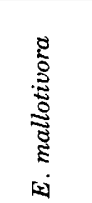 & 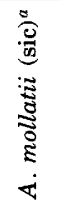 & 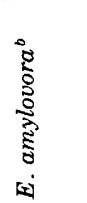 & 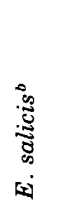 & 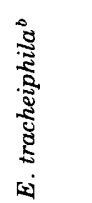 & 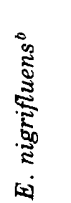 & 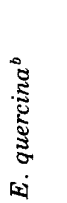 & 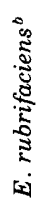 \\
\hline Anaerobic growth & $t^{c}$ & - & \pm & \pm & \pm & + & + & + \\
\hline Growth factors required & + & NT & + & + & + & - & + & - \\
\hline $\mathrm{H}_{2} \mathrm{~S}$ from cysteine & - & + & - & + & + & + & + & + \\
\hline Urease & - & NT & - & - & - & + & - & - \\
\hline Growth at $36^{\circ} \mathrm{C}$ & - & NT & - & - & - & + & + & + \\
\hline Gluconate oxidation & - & $\mathrm{NT}$ & - & - & + & - & - & - \\
\hline Sucrose, reducing compounds & + & NT & + & + & d & - & + & - \\
\hline Pectate degradation & - & NT & - & + & - & - & - & + \\
\hline Pink diffusible pigment & - & $\mathrm{NT}$ & - & - & - & - & - & + \\
\hline Acetoin & + & NT & + & + & d & + & + & - \\
\hline Mucoid growth & + & $\mathrm{NT}$ & + & + & - & - & + & + \\
\hline Motility & + & - & + & + & + & + & + & + \\
\hline Nitrate reduction & - & - & - & - & - & - & - & - \\
\hline DNase & NT & NT & - & - & - & - & - & - \\
\hline Gelatin liquefaction & - & + & + & - & - & - & - & - \\
\hline Phenylalanine deaminase & - & NT & - & - & - & - & - & - \\
\hline Indole & - & - & - & - & - & - & - & - \\
\hline Gas from glucose & - & NT & - & - & - & - & - & - \\
\hline Casein hydrolysis & - & NT & - & - & - & - & - & - \\
\hline Blue pigment & - & $\mathrm{NT}$ & - & - & - & - & - & - \\
\hline Yellow pigment & - & NT & - & - & - & - & - & - \\
\hline Cottonseed oil hydrolysis & - & NT & - & - & - & - & - & - \\
\hline KCN inhibition & + & NT & + & + & + & + & + & + \\
\hline$\underset{\left({ }^{\circ} \mathrm{C}\right)}{\operatorname{Maximum}}$ growth temperature & $32-33$ & 35 & $32-34$ & 35 & $32-34$ & 38 & 38 & 38 \\
\hline Growth in $5 \% \mathrm{NaCl}$ & - & NT & NT & NT & NT & NT & NT & NT \\
\hline Phosphatase & - & NT & $\mathrm{NT}$ & $\mathrm{NT}$ & NT & NT & $\mathrm{NT}$ & NT \\
\hline
\end{tabular}

a Takimoto, 1930.

${ }^{b}$ See reference 5.

$c$ Symbols: see footnote $c$, Table 2 . 
no longer extant, and therefore they cannot be compared with those of $E$. mallotivora.

\section{ACKNOWLEDGMENTS}

I thank R. A. Lelliott for his generosity in supplying Erwinia amylovora antiserum and for valuable suggestions and advice given during preparation of the manuscript, $T$. Kimura for his kind help in determining DNA base compositions, and N. Okabe for his encouragement and advice throughout the study.

\section{REPRINT REQUESTS}

Address reprint requests to: Dr. Masao Goto, Faculty of Agriculture, Shizuoka University, Shizuoka 422, Japan.

\section{LITERATURE CITED}

1. Buchanan, R. E., J. G. Holt, and E. F. Lessel, Jr. (ed.). 1966. Index Bergeyana. The Williams \& Wilkins Co., Baltimore.

2. Cowan, S. T., and K. J. Steel. 1966. Manual for the identification of medical bacteria. Cambridge University Press, London.

3. Dye, D. W. 1968. A taxonomic study of the Genus Erwinia. 1. The "amylovora group." N. Z. J. Sci. 11:590607.

4. Klement, Z., G. L. Farkas, and L. Lovrekovich. 1964. Hypersensitivity reaction induced by phytopatho- genic bacteria in the tobacco leaf. Phytopathology 54:474-477.

5. Lelliott, R. A. 1974. Genus Erwinia, p. 332-340. In Bergey's manual of determinative bacteriology, 8th ed. The Williams \& Wilkins Co., Baltimore.

6. Lelliott, R. A., E. Billing, and A. C. Hayward. 1966. A determinative scheme for the fluorescent plant pathogenic pseudomonads. J. Appl. Bacteriol. 29:470-489.

7. Marmur, J., and P. Doty. 1962. Determination of the base composition of deoxyribonucleic acid from its thermal denaturation temperature. J. Mol. Biol. 5:109-118.

8. Okabe, N. 1949. Bacterial plant pathology. (In Japanese). Asakura Book Co., Tokyo.

9. Okabe, N., and M. Goto. 1955. Bacterial plant diseases in Japan. I. A list of bacterial diseases and their pathogens. Rep. Agr. Shizuoka Univ. (In Japanese with English summary) 5:63-71.

10. Schildkraut, C. L., J. Marmur, and P. Doty. 1962. Determination of the base composition of deoxyribonucleic acid from its buoyant density in $\mathrm{CsCl}$. J. Mol. Biol. 4:430-433.

11. Society of American Bacteriologists. 1957. Manual of microbiological methods. McGraw-Hill Book Co., Inc., New York.

12. Takimoto, S. 1930. Bacterial leaf spot of Akamegashiwa. J. Plant Prot. Tokyo. (In Japanese) 17:513-515.

13. Tuite, J. 1969. Plant pathological methods, fungi and bacteria. Burgess Publishing Co., Minneapolis, Minn. 